\title{
Values and identity of contemporary military officer in the context of national security
}

\author{
Paulius BALSYS ${ }^{1}$ \\ ${ }^{1}$ Faculty of sociology, Lithuanian social research center, A. Goštauto st. 9, LT-01108, Vilnius, Lithuania. \\ E-mails: ${ }^{1}$ paulius.balsys@mil.lt,pauliuqas@gmail.com.
}

\begin{abstract}
Military is an institution which is one of the most significant national security guarantees. Lithuanian armed forces military psychologists findings of soldiers who leave the service before time show that the main reason is that organization is not able to ensure individual needs of personnel. The problem of this report is - how the military organization is able to implement function of national security combining individual officers and collective organizational values in the context of contemporary society? For this research was applied qualitative research method, using semi-structured interview technique.
\end{abstract}

KEY WORDS: Military sociology, identity, ambivalence, individualism, collectivism, values

\section{Introduction}

Military is one of the most important national security tools which directly implements security tasks. As institution military represents collective values, which lay in military 's laws (statutes, orders, oaths). These values create meaning of sacrifice for higher good, absolute hierarchy, subordination for authority. Collective values are essential and immutable for organization for ages. These values are closely related with military innate tasks. In extreme situations from soldiers it requires to act brave and unquestionable, sometimes to lay down one 's life.

On the on hand, complex of institutional norms of organization forms officer 's professional identity. But recent research findings that were completed by Lithuanian armed forces military psychologists show, that officer 's identity is strongly influenced by institutions values face challenges rising from officers' individual needs. Lithuanian armed forces military psychologists' findings2 of soldiers who leave the service before time 3 show that the main reason is that organization is not able to ensure individual needs of personnel. Soldiers who leave the army before time claim, that they are not satisfied with conditions and abilities to combine home environment, family (individual life) with service issues. Nowadays military convergence with civilian organizations not only leads to proceduralorganizational change.

The problem of this report is - how the military organization can implement function of national security combining collective organizational values in the context of contemporary society?

The aim of this research is to represent values aspects of contemporary military officers' identity which show the conflict between society and organizational (collective) values.

There are several meaningful researches about military organization that are closely related with Lithuanian army values and identity. Jūratė Novogrockienė (2005) published an article „Kariuomenès transformacija XXI amžiuje: Lietuvos atvejis" In this article there is assessed transformation of military organization in the nowadays and impact of global environment. Jolanta Aleknevičienè and others (2015) published a research Motyvacija tarnauti Lietuvos kariuomeneje where discovered motives of contract and voluntary service soldiers. This research reveals and categorize prevailing motives and values in Lithuanian armed forces. This research is unique, because reveals conflicted aspects of nowadays officer 's professional identity cause of ambiguous values conflict- institutional and societies.

Article consists of four parts. In the beginning it is discussed theoretical knowledge which is crucial for empirical data research. Later, very briefly it is presented research methodology which was chosen to reach the goal of this work. After methodology it is provided empirical data which is linked with theoretical knowledge. The end of this work is finished with conclusion part where is discussed research results and its impact on the Lithuanian armed forces and national security.

\footnotetext{
${ }^{1}$ Corresponding author.

E-mail address: paulius.balsys@mil.1t.

${ }^{2}$ Dr. Jono Basanavičiaus medicinos tarnybos karo psichologų išvada (2017) dèl anksčiau laiko nutrauktų tarnybos sutarčių.

${ }^{3}$ According military statutes (KASOKTİ) it is estimated that officer in order to get military pension has to serve at least 25 years.
} 


\section{Officer 's Professional Identity and Values Conflict}

The term of social identity became popular and often mentioned in the end of $20^{\prime}$ th century society [6]. According researchers to talk about identity as social construct is especially relevant in modern society, because of the great distribution in social classes, professions, various roles [6]. Algimantas Valantiejus claims that it is impossible to talk about social identity without of social choices- to ask your self ,who am I? "as a distinctive individual you can just in social diversity.

Talking about military organization it is important to stress, that identity of individual is very strictly framed in normative documents and statutes of organization4. According the discourse which lay in military statutes, collective values are more important than personal affairs of the individual (KASOKTI, 1998). Normative documents not only tell what is allowed and what is prohibited for a soldier. These documents construct social role, image of a ,good officer “. It is an identity which is shaped by institution. These values, as mentioned before, are collective, demanding for officers to refuse private life and to sacrifice your own needs in some cases (for example the system of officers' rotation or to sacrifice your own life). Collective values reflect into guidelines of Armed forces. There are eight values which are mandatory for each soldier - patriotism, loyalty, sacrifice, bravery, honesty, respect, honor and principledness (Vision of the Lithuanian Armed Forces, 2012). This institutional part forms officer 's identity which might become a struggle as other authors [3] and recently made military psychologists research show.

The concept of identity is applied both in sociology and psychology. Identity theory says that individual tends to assign themselves with some groups which has clearly expressed values, beliefs, and norms [6]. People naturally are tended to categorize each other in groups according to differences (professions, hobbies, religion). As Peter Berger claims social ,self “ is formed through socialization process with subjectively and objectively marked differences [8]. Sociologically, social identity is shaped by culturally relative forms. Berger and Luckmann mark difference between sociological and psychological definition understanding identity. Sociologically identity is a social product, when individual identifies himself for example as ,,a soldier “, or „,a man“. This identification gives culturally marked features like attitudes, beliefs, values. It might determine unconscious psychological reactions like „manly“emotions, reactions [8]. But why is it important to stress culturally different modernity talking about identities? How nowadays society might affect and interact with traditional military officer's identity?

Berger and Luckman in their classical work The social construct of reality discuss the concept of alteration of identity [8]. Authors claim, that when there exist few social environments one of them might offer individuals ,effective plausibility structure“. In such conditions it becomes as a base or ,a social laboratory“ of identity transformation. The structure which is defined as plausibility is the main criteria for individuals to create a strong identification. Berger and Luckmann claim that this effective identification is based on childhood experience linking with significant others [8]. Such attractive structure marked as plausibility transforms individual's world, becoming the main world and displace previous social identification.

Legkauskas in his research converge psychological and sociological concepts of identity denying confrontation between individual and collective identity [6]. Author in his work talks about conflict which lays in identity or might rise between different identities in culturally diverse environments. If environment suggests more identity alternatives, it might provoke a conflict between attractive and unacceptable identity choices. Legkauskas claims, that conflict between different contents might exist even if self-identity coincides with self-consciousness. It means that individual might feel discomfort in such environment [6].

Thoughts about conflict between different identities is more precisely expressed as a concept of social ambiguity. According scientists (Luscher, K., Pillemer, K.) identities are incompatible attitudes, beliefs, and behaviours that are driven by values cause of different social environments. Socially structured (determined) identities of individuals at the same time might belong to several identities. Furthermore, at the same time ambiguous social identities might reject social norms, beliefs, attitudes, whom belong. These ideas are very meaningful in the context of modern society. Such conflictic duality rise when you, as individual have ambiguous values, norms or expectations [10] (Fig. 1).

According Merton [9], such situation is usual, when individual identifies themself with several social roles, which capacities incompatible social norms, rising from those identities. For example, a compatibility of two different roles for women who considers herself as ,,a good mother“ but she is also a worker, working hard and spending most of the time in a factory. The result of such conflictic duality interaction is social pressure which is caused by social tension, contradictory feelings [3]. Women might feel disappointed not being able to coordinate socially perceived mother's and worker's roles.

Military sociologists, in the end of previous century started to recognize contemporary society influence to

4 In lithuanian armed forces are used Karo tarnybos statutas (angl. military service statute) and Krašto apsaugos sistemos organizavimo ir karo tarnybos įstatymas (angl. The law of national defense system organisation and military service) 
soldiers identity. Francis Galligan noticed that army expectations that were traditionally specified with organizational collective nature of organization started getting harder to find their place in modern individualistic western societies [11]. Francis Galligan claim, that the main problem could be mentioned as the gap between army expectations, ethical standards from officers and how military individuals actually perceive their service [11]. Other authors (Sloane, Janowitz) claim that nowadays officer has to suffer identity duality- being in different roles.

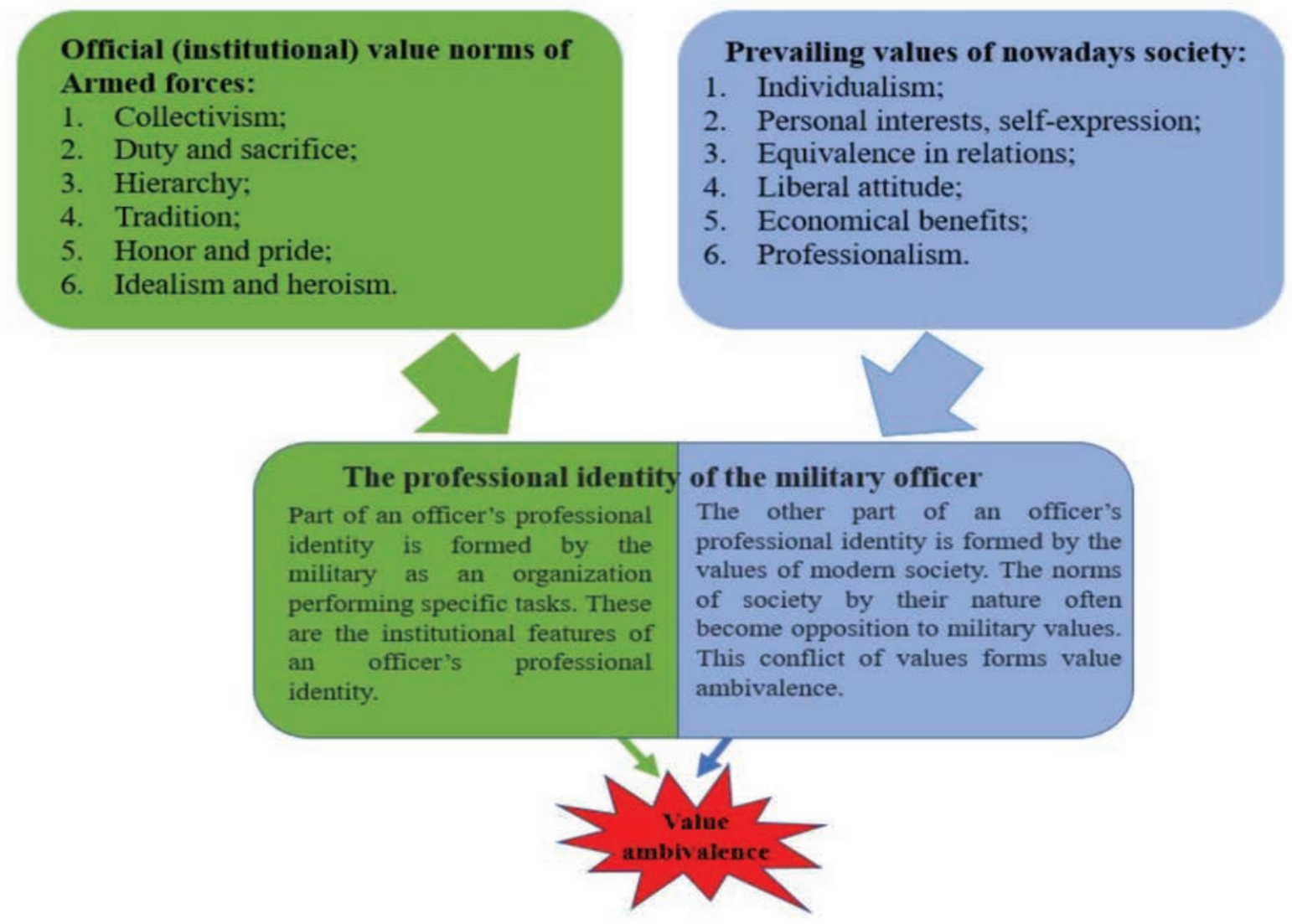

Fig. 1. Accumulation of ambivalence in the officer's professional identity (Balsys P., 2019).

Later Morris Janowitz (1960) details it- modern military has two (dual identity) starting points. In one side, there is institution (author means institutional values), which serves for traditional, heroical (collective) army`s needs related with national security. But on the other side, there are „military managers“, who are linked with pragmatic, bureaucratic personal needs. This conflict between different sources determines, that officers gradually moving away from traditional and institutionally expected identity. In order of being patriotic, heroic, brave officer becomes administrative problems solver. Moving later Charles Moskos creates much more detailed problem solving model [3].

Classical Charles Moskos modern armies institutional/occupational research model by it's meaning also express the conflict which rise because of different values contents (institution versus society/civilian) [3]. The occupational part of the model explains military organization's value direction taken from society which is specific to the civilian sector. Moskos claim that occupational part forms officer's identity, it is implying a priority which is directed to self-interest. In this context, collective values become secondary. Military become perceived as any civilian job. Institutional part in this model still represents opposition- concept of values which are necessary to ensure innate tasks of armed forces. Albeit Moskos model received criticism, but it's content help comprehensively understand identity problem of nowadays military officer [3].

Overview of theory and research leads to conclusion. Modern societies structure and social diversity are factors that might become one of the most important challenges for national defense security and policy of personnel. Institutional officer's identity remains crucial for national defense tasks implementation because defense tasks always require specific values, attitude and beliefs. Nowadays convergence of civil-military relations might be challenging. Contemporary society trends that are specific with such features as individualistic, hedonistic, liberal values suggests what Berger and Luckmann call plausible identities foundation for armed forces individuals. Traditional, demanding institution's values become difficult to accept, old-fashioned for nowadays officers. 


\section{Methodology}

For this research was applied qualitative research method, using semi-structured interview technique. Interview was separated in two parts. At first, officers were asked to talk about their personal experience, to tell their service story. In the second part, officers were asked their opinion about various issues and attitudes towards service. This part allowed to analyze deeper connected with identity and values deeper. Research was done also using phenomenological approach. During interview respondents were asked to analyze deeper the meaning of their own experience, to value different service situations and the meanings.

Empirical data was collected in the period from 2018-11 till 2019-02. The duration of each interview was between 30-40 minutes. At all 10 officers, Lithunian military Academy graduates were interviewed. Each officer having more than 10 years military service experience ( 8 captains, 2 majors). Most of the officers now are serving in different units staffs, educational institutions also had management for unit experience. All interviews were taken in their units, during their service time, wearing uniforms. Interviews were recorded using a voice recorder. According to the research ethics respondents have fictional names.

For the analysis was chosen case study method. This approach was useful in the way of understanding exceptional and phenomenal cultural environment of armed forces and contemporary society. Case study provide effective analytical tools to understand problem of identity conflicts. Empirical data was analyzed through method of content analysis. Text was categorized into main categories, subcategories and codes. These categories and subcategories clarified during text analysis. Empirical data is linked and interpreted through theoretical base using deductive access.

\section{Civil Identity}

Sociologists talking about modern organized structure army mention it's important feature- civilianization $[4,5,14]$. Authors link this feature with newly raised civil-military relations during the Cold war. This process is called unionization and was discussed in G. Caforio study [4]. It means that nowadays military officers don't strictly identify their profession just in frames of institution. This trend determines, that officer's profession looks for identification elsewhere. What characterizes civilianization feature? Probably one of the most wide spread feature is that officers do not exclude warrior's profession from others. Or vice versa, officers identify warriors' profession with civilian's ones (table nr. 1).

Table 1

Unionization with civil sector

\begin{tabular}{|c|c|c|}
\hline Feature of identity & Authors & Interview extracts \\
\hline \multirow[t]{3}{*}{$\begin{array}{l}\text { Unionization } \\
\text { with civil } \\
\text { sector }\end{array}$} & \multirow[t]{3}{*}{$\begin{array}{l}\text { Janowitz (1960), } \\
\text { Segal (1983), Ca- } \\
\text { forio (2006). }\end{array}$} & $\begin{array}{l}\text { There are thousands of different civilian jobs... To begin with... I don 't } \\
\text { know... Sales managers.... Where he sells products for millions and } \\
\text { also feel stress... So the officer in that background do not distinguish } \\
\text { unless you compare it to something very purposefully... (Arnoldas 40) }\end{array}$ \\
\hline & & $\begin{array}{l}\text { I think both civilian and military have their similarities. In the mil- } \\
\text { itary, there are those who work with people, such as the units com- } \\
\text { manders, and those who work with papers, documents. It is just the } \\
\text { same in a civilian job as some boss of the shift and some kind of sitting } \\
\text { clerks... (Andrius, 42) }\end{array}$ \\
\hline & & $\begin{array}{l}\text { During the peace time an officer is that who organizes exercises, do- } \\
\text { ing administrative work and so on, and in war conditions, other things } \\
\text { would be important...Certainly, officers and managers are similar.. In } \\
\text { every day routine, officers and managers are especially similar, they } \\
\text { do very similar procedures... (Justas, 36) }\end{array}$ \\
\hline
\end{tabular}

The aspect of civilianization in military officer's identity just confirms statements, that nowadays military is closely related with civilian environment and changed quite sharply in the peace time. This aspect and empirical data shows that nowadays officer's identity is not strictly constructed into frames of institution.

Secular, civilian job standards determine that nowadays officers do not emphasize so firmly values that lay in normative documents of the armed forces. The identity of officer quite „,comfortably“ has settled down next to other civilian jobs. This aspect of identity is important in the context of national security tasks implementation. Aspect of civilianization contributes to what Segal claims, that nowadays warrior's will to fight is decreased [14]. 


\section{The Decline of Ideals}

As was mentioned before, army is an institutional organization [3]. Institutional structure of military is based on collective values which importance is crucial for successful functioning and performing tasks. Collective values as Morris Janowitz (1960) claims serves for traditional, heroical (collective) army's needs related with national security.

These values are still mentioned in the Commander's of Lithuanian armed forces vision (2012). But how to keep these ideals still valid in the liberal societies during the peace time? It is two different social environmentsinstitutional (armies) and societies. These norms become ambiguous cause of different value content [9]. As Moskos claims- two different poles- institutional and occupational [3]. These ambiguous identities are incompatible attitudes, beliefs that lead to identity conflict driven by different social environments (Table 2).

Empirical data shows that officers are not able to identify themselves with collective ideals naturally in their daily routine. As major Arnoldas who was asked about these values prevalent in the military says- ,these values are dead“. As Berger and Luckmann [8] claim identity is shaped through socialization process which requires objective relative forms to substantiate social being. Identity is created through culturally relative forms.

Table 2.

The decline of ideals

\begin{tabular}{|l|l|l|}
\hline \multicolumn{1}{|c|}{ Feature of identity } & \multicolumn{1}{|c|}{ Authors } & \multicolumn{1}{c|}{ Interview extracts } \\
\hline The decline of ideals & $\begin{array}{l}\text { Janowitz (1960), } \\
\text { Moskos (1981). }\end{array}$ & $\begin{array}{l}\text { Over the time, when routine comes along, we forget those val- } \\
\text { ues... You can't keep those values and think about them constantly... } \\
\text { It's the same bureaucracy that spread out so hardly that become dif- } \\
\text { ficult to implement... Then you just try to make it as flexible and sim- } \\
\text { ple as possible. These values are not even needed here... they need } \\
\text { simple, rational thinking, solution. Those values are not relevant in } \\
\text { this area. They become relevant in emergent and critical situations } \\
\text { (Saulius, 39) }\end{array}$ \\
\hline $\begin{array}{l}\text { It is not very easily tangible.... That sacrifice... if you don 't jump to } \\
\text { the fire save someone's life.... On the other hand, is it a sacrifice } \\
\text { (make a presentation over the weekend)? Is it simply apart of the } \\
\text { job or service? How about that honor? What are the criteria for } \\
\text { honor? These are perhaps bigger, feats of war, greater potential for } \\
\text { those feats. And in your daily activities, you do your job there ... } \\
\text { but it's hard to clearly define what is it .. Every value ... There is no } \\
\text { circumstance that somehow it can brighten up and identify all those } \\
\text { values... () }\end{array}$ \\
\hline
\end{tabular}

This aspect shows that nowadays officers are not tended to assign their identity and to move away from culturally and close in value civil identity. Decline of ideals shows, that nowadays officers show that institution is not so more strictly source to derive professional identity. Civil value aspects in some cases might be even more significant.

\section{Self-Realization and Military Identity}

Many authors, philosophers describe contemporary society as liberal individualistic and hedonistic (Mannigart, 2006). As Ronald Inglehart claims, in the post-material society influence of survival values begins to decrease. In economically stable countries values are changing in the direction of self-realization [13].

The main feature of such value change is that personal interests become more important for individual. This feature is also connected with individual perception of your own place in the community. The sense of belonging to larger community, commitment for the collective diminishes. Priority becomes your own needs. Nowadays individual needs are higher than collective commitment. Francis Galligan in previous century noticed that there is newly appearing problem of warrior's ethos [11]. The standards and expectations which rise from institution become inconsistent with service perception of contemporary officers. Another famous author Charles Moskos [3] also mentioned institutional officer's identity which changes towards civilian values- occupational. Aspect of individualism in collective values propagating military institution leads to ambivalent situation (table nr. 3). According authors Luscher and Pillemer [7], it is caused by incompatible attitudes, beliefs, and behaviors that are driven by collision of different social environments. 
Self-realization and military identity

\begin{tabular}{|l|l|l|}
\hline Feature of identity & \multicolumn{1}{|c|}{ Authors } \\
$\begin{array}{l}\text { Wnith chization } \\
\text { sector }\end{array}$ & $\begin{array}{l}\text { Janowitz (1960), } \\
\text { Segal (1983), Man- } \\
\text { nigart (2006). }\end{array}$ & $\begin{array}{l}\text { The collective. First of all, the officer has to unite and make a team. } \\
\text { Then I say, we were commanders who participated... In the battalion } \\
\text { that I was serving there was a commander and a team around him... } \\
\text { Nobody counted time or minutes there. Nowadays everything is dif- } \\
\text { ferent.. At five o'clock everyone goes home. The company command- } \\
\text { er participated with us- at five o'clock we used to go to cafe for a } \\
\text { meal. Of course, we were drinking a beer. You know everyone's busi- } \\
\text { ness. But there was tradition, there was a commander! (Arnoldas } 40)\end{array}$ \\
& $\begin{array}{l}\text { If a person is creative, very creative, it will be difficult for him in } \\
\text { the military because a creative person needs freedom, many ideas } \\
\text { are needed to realize them... When artistic person or creative per- } \\
\text { son comes to the military, it becomes difficult for him because no } \\
\text { one will take those thoughts from him. Nobody needs his ideas... } \\
\text { (Mindaugas 39) }\end{array}$ \\
\hline $\begin{array}{l}\text { As a result, our talented people in the sergeant Corps who are } \\
\text { graduating higher education leave the service. They see that it is } \\
\text { too cramp for them to be in some sort of sergeant position. When he } \\
\text { has the higher education and he can overthrow mountains! When it } \\
\text { comes to officers with some sort of finances or IT technology. I can } \\
\text { do much more in civilian life. That restriction on his. Very difficult. } \\
\text { (Mindaugas 39) }\end{array}$ \\
\end{tabular}

Empirical data and recently done researches by Aleknevičienè and other [12] show, that self-realization is one of the most significant features to met in nowadays officer's identity. The base of collective values of armed forces form a completely opposite value environment from the one you can meet in modern society [13]. Selfrealization just confirms that nowadays officer's identity is not so strictly framed by institutional values of armed forces. Permanent, close interaction with society (civil-military relations) creates conflict diversity for professional identity. This environment based on ambiguous social norms create social tense that reflects in empirical data and researches of others scientists [10].

\section{Conclusions}

The aim of the article was to come out with values aspects of conflict military officer's professional identity which would show a confrontation between two values sources: society and organizational (collective). Research has revealed three the most significant aspects of conflict officer's identity: civilian identity, decline of ideals and self-realization. These newly raised identity's aspects show that the military's value is tended to decrease cause of the increased values influence from the contemporary society. Civil-military relations convergence determines transformation of nowadays officers corps.

Society's origin features of officer's identity fate that individual needs (like self-realization) might be prioritized in the background of institution values. The cause of this conflict and the prioritization of the public's value pole may result officers' early termination of service. Civilian features and decreased ideals show that contemporary officers have no such strong identity relation with institutional values. These officer's self-concept professional features reveal a change in a professional identity- transformation and alignment with ordinary civilian work positions. It shows that unionization process has led officers identity to some adaptation in a structure of work of contemporary peace time society.

The change of warrior's identity is an important aspect in ensuring national defense tasks. This problem will remain relevant in the process of transformation of society. Because Armed forces as institution must keep and cherish it's core value features like self sacrifice, patriotism, allegiance to ideals. Officer's identity conflict might also increase as society changes. Because armed forces are always tied to the qualities, values of individuals who come to serve. Changes in society will determine changes in the army. 


\section{References}

1. Huntington S., The Soldier and the State: The Theory and Politics of Civil-Military Relations, Cambridge: The Belknap Press, 1957 m.

2. Petrauskaitė A., Merkelienė Kazlauskaitė R., Gedminienė R., Šalies saugumas ir gynyba, Generolo Jono Žemaičio Lietuvos Karo Akademija, 2016 m., Vilnius.

3. Moskos C., Institution versus Occupation: contrasting models of military organization, Department of Sociology Northwestern University, $1981 \mathrm{~m}$.

4. Caforio G., Handbook of the sociology of the military, Italian Inter university Centre of Historical and Military Studies, $2006 \mathrm{~m}$.

5. Janowitz M., The Professional Soldier: A Social and Political Portrait, Free press, $1960 \mathrm{~m}$.

6. Legkauskas V., Tapatumas ir savimonè: jungtis tarp psichologijos ir socilogijos, Vytautas Magnus university, $2000 \mathrm{~m}$.

7. Luscher K., Pillemer K., Intergenerational ambivalence: A new approach to the study of parent - child relations in later life, Journal of marriage and family vol. 60 (may), p. 413 - 425, 1998 m.

8. Berger P., Luckamann T., The social construction of reality, Penguin books, 1966.

9. Merton R., Sociological ambivalence and other essays, Collier Macmillan publishers, London, p. 3 - 32, 1976

10. Yair G., "Ambivalence”, The Blackwell Encyclopedia of Sociology, Oxford: Wiley-Blackwell, p. 127 - 128, 2007.

11. Galligan F. B., Military Professionalism and Ethics, Newport: The Naval War College center for advanced research. p. $6-80,1979$.

12. Aleknevičienė J., Pocienė A., Vileikinė E., Motyvacija tarnauti Lietuvos kariuomenèje. Vilnius: Generolo Jono Žemaičio Lietuvos karo akademija. p. 40 - 54., 2015 m.

13. Roales J., Segura A., Intergenerational Differences in Materialism and Postmaterialism Values in a Spanish Sample, International Journal of Psychology and Psychological Therapy. p. 499 - 512, 2010 m.

14. Segal D., Change in military organization, JSTOR, Vol. 9, p. 151-170, 1983.

15. Balsys P., Ambivalentiška karininko profesinè tapatybė, Kultūra ir visuomenè, Socialinių tyrimų žurnalas VDU, 2019 m. Online: https://www.vdu.lt/cris/bitstream/20.500.12259/102744/1/ISSN2335-8777_2019_N_10_2. PG_71-85.pdf

16. Balsys P., Karininko profesinis identitetas, magistrantūros baigiamasis darbas, VDU, 2019 m. Online: https:// www.vdu.lt/cris/handle/20.500.12259/70069 